JURNAL KEPENDUDUKAN INDONESIA

p-ISSN : 1907-2902 (Print)

e-ISSN : 2502-8537 (Online)

\title{
PROFIL PENDUDUK TERKONFIRMASI POSITIF COVID-19 DAN MENINGGAL: KASUS INDONESIA DAN DKI JAKARTA
}

\section{(THE PROFILE OF POPULATION THAT CONFIRMED POSITIVE FOR COVID-19 AND DIED: INDONESIA AND DKI JAKARTA CASES)}

\author{
Deny Hidayati \\ Pusat Penelitian Kependudukan, Lembaga Ilmu Pengetahuan Indonesia \\ Korespondensi penulis: denyhidayati001@gmail.com
}

\begin{abstract}
This paper discusses the population that confirmed positive for COVID-19 and died in Indonesia and DKI Jakarta, which is epicentre of corona virus transmission in this country. The trend of population confirmed positive COVID-19 continues to increase and fluctuate every day, while the percentage of population deaths tends to decline. The paper using secondary data revealed that male residents were more vulnerable to COVID-19 than women. The number of male population confirmed positive corona virus is higher and the percentage of death is much higher. Covid-19 attacks all age groups, but the population is over 46 years, especially 60 years and above, more vulnerable than other age groups. Infants, toddlers and children who are detected positively have a low percentage, but the quantity is quite large. The population risk reduction policy for COVID-19 is indispensable for all residents with priority given to more vulnerable groups in Indonesia and DKI Jakarta.
\end{abstract}

Keywords: population, sex, age group, vulnerable, COVID-19

Paper ini mendiskusikan profil penduduk yang terkonfirmasi positif COVID-19, dan yang meninggal dunia di tingkat nasional (Indonesia) dan provinsi (DKI Jakarta) yang menjadi lokasi pertama terdeteksinya penduduk positif virus korona dan episentrum penularan COVID-19 di negeri ini. Profil penduduk difokuskan pada variabel utama demografi, yaitu jenis kelamin dan kelompok umur. Pemahaman tentang profil penduduk diperlukan untuk mengetahui kelompok rentan COVID-19 agar dapat dilakukan penanganan dan upaya mitigasi tepat sasaran untuk memutus penyebaran virus korona. Paper ini menggunakan data sekunder, terutama dari situs resmi pemerintah di tingkat nasional (Gugus Tugas Percepatan Penanganan COVID-19 Indonesia) dan DKI Jakarta (Gugus Tugas Percepatan Penanganan COVID-19 DKI Jakarta). Pengumpulan data juga dilakukan melalui desk review hasil-hasil penelitian dan referensi yang relevan.

Tren penduduk Indonesia yang terkonfirmasi positif COVID-19 terus meningkat sejak pertama diumumkan, dari 2 orang pada 2 Maret 2020 menjadi 24.538 orang tanggal 28 Mei 2020 (Gambar 1). Peningkatan jumlah penduduk berfluktuasi setiap harinya dengan penambahan kasus positif tertinggi sebanyak 973 orang terjadi 21 Mei 2020. Tingginya penambahan kasus positif menurut pemerintah terkait dengan semakin masif dan tersebarnya kegiatan test COVID-19. Tetapi sebagian stakeholders mengungkapkan banyaknya pertambahan penduduk positif karena rencana pelonggaran Pembatasan Sosial Berskala Besar (PSBB) dan persiapan Idul Fitri yang berdampak pada banyaknya kerumunan warga di bandara, stasiun, pusat perbelanjaan dan pasar tradisional. 
Gambar 1. Tren Penduduk Terkonfirmasi PositifCOVID-19 dan Meninggal di Indonesia dan DKI Jakarta, 2 Maret - 28 Mei 2020

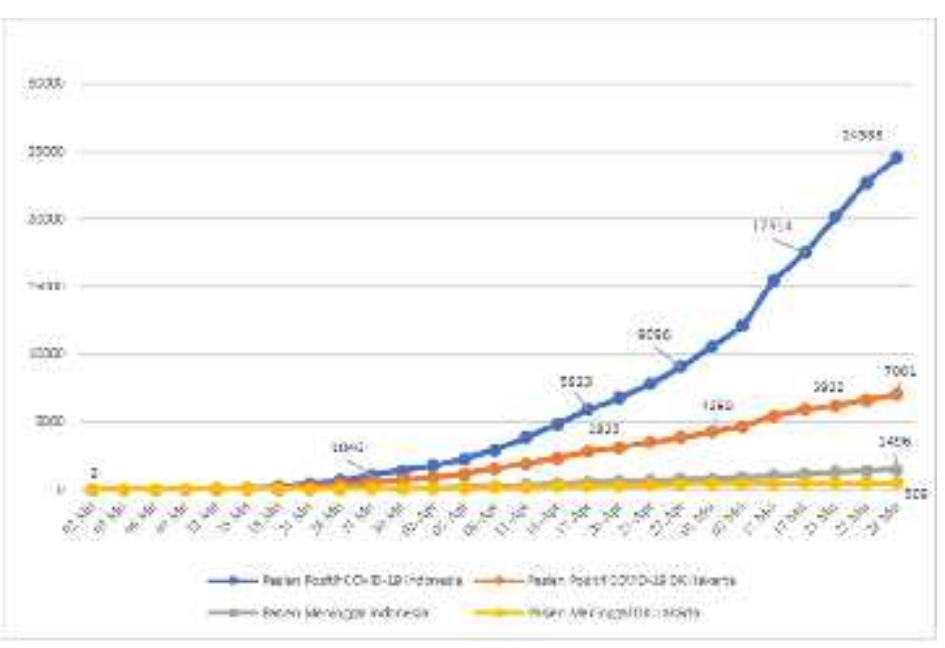

Sumber: Gugus Tugas Percepatan Penanganan COVID-19 Indonesia, 29 Mei 2020

Penduduk yang positif COVID-19 tersebar di hampir seluruh wilayah Indonesia dengan jumlah kasus terbanyak berada di DKI Jakarta, mencapai 7.001 orang atau 28,5 persen tanggal 28 Mei 2020 (Gugus Tugas Percepatan Penanganan COVID-19 Indonesia, 2020). Dari grafik pada Gambar 1 diketahui awal terdeteksinya COVID-19, garis kurva penduduk yang positif di Indonesia dan Jakarta jaraknya sangat berdekatan, karena Jakarta merupakan pusat penyebaran virus korona di Indonesia. Namun sebulan kemudian jarak kedua garis kurva tersebut mulai menjauh dan semakin melebar. Kondisi ini mengindikasikan pertambahan jumlah penduduk positif COVID-19 di Indonesia sangat signifikan dan menyebar luas sampai ke seluruh provinsi, terutama Jawa Timur, Jawa Barat, Jawa Tengah, dan Sulawesi Selatan.

Jumlah kematian penduduk yang diumumkan pemerintah terus meningkat, namun tren persentasenya terus menurun pada periode 2 Maret - 28 Mei 2020. Pada fase awal terdeteksinya COVID-19, kematian penduduk sangat tinggi, yaitu 9,5 persen pada 2 April 2020 dan hanya turun sedikit menjadi 9,0 persen pada 16 April 2020. Pada akhir April kematian masih tinggi, bahkan tertinggi di Asia Tenggara (CSIS, 2020; Wahyuni, 2020; Wong dkk., 2020). Kematian terus menurun mencapai 6,1 persen pada 28 Mei 2020, seiring dengan gencarnya informasi tentang pentingnya melaksanakan physical dan social distancing serta mulai dilaksanakannya PSBB di DKI Jakarta (10 April 2020) , Jawa Barat (15 April 2020 untuk Bogor, Depok dan Bekasi), Banten (18 April untuk Tangerang Raya).
Kematian penduduk di Jakarta mempunyai pola serupa dengan di Indonesia, tren persentasenya juga menurun dalam periode tersebut. Namun, persentase kematian di ibukota lebih tinggi daripada di Indonesia, yaitu 10,5 persen pada 2 April 2020. Persentase ini turun sedikit menjadi 9,2 persen pada 2 Mei 2020, dan terus menurun meskipun persentasenya masih tinggi ( 7,3 persen) pada 28 Mei 2020 (Gugus Tugas Percepatan Penanganan COVID-19 Indonesia, 2020).

Angka kematian penduduk karena COVID-19 di Indonesia masih dalam perdebatan. Sebagian stakeholders, terutama IDI, pakar epidemiologi, praktisi, dan pemerhati kesehatan, memperkirakan kematian penduduk yang positif jauh lebih tinggi (Djalante dkk., 2020; Wahyuni, 2020; WHO, 2020a). Mereka beranggapan data kematian dari pemerintah kurang transparan. Pemerintah hanya menghitung jumlah kematian berdasarkan jumlah penduduk yang terkonfirmasi positif, sedangkan kematian penduduk dengan status Orang Dalam Pemantauan (ODP) dan Penduduk Dalam Pengawasan (PDP) yang hasil tesnya belum keluar serta kematian penduduk dengan gejalagelaja COVID-19 tidak masuk dalam perhitungan. Perkiraan mereka tentang lebih banyaknya kematian juga didukung data akumulasi pemakanan di DKI Jakarta yang naik drastis sejak akhir Maret, dari 89 pada 23 Maret 2020 menjadi 456 tanggal 2 April 2020 dan 2.432 pada 28 Mei 2020 (Gugus Tugas Percepatan Penanganan COVID-19 DKI Jakarta, 2020). (Gambar 2). 
Gambar 2. Akumulasi Pemakaman Jenazah dengan Protap Penanganan COVID-19 di DKI Jakarta, 2020

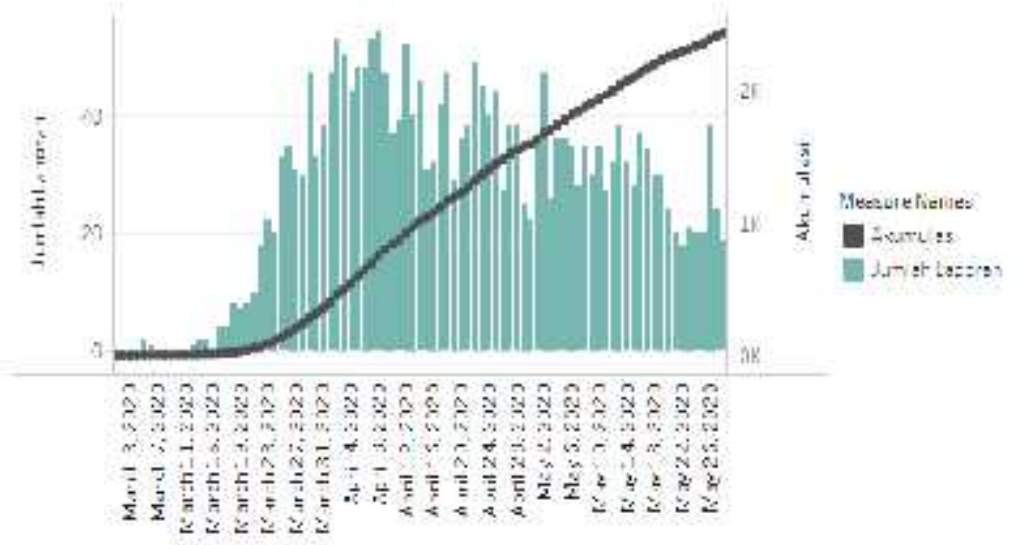

Sumber: Gugus Tugas Percepatan Penanganan COVID-19 DKI Jakarta, 29 Mei 2020

COVID-19 menyerang menyasar semua jenis kelamin (laki-laki dan perempuan). Grafik pada Gambar 3 memperlihatkan bahwa laki-laki mendominasi penduduk yang terkonfirmasi positif COVID-19 dan meninggal di Indonesia. Penduduk laki-laki yang positif mencapai lebih dari separoh total mereka yang terdeteksi positif tersebut. Keadaan laki-laki jauh lebih buruk daripada perempuan. Laki-laki yang meninggal jauh lebih banyak, persentasenya berbeda signifikan dengan perempuan. Namun perempuan tetap perlu waspada, karena persentase yang terkonfirmasi positif masih tinggi.

Gambar 3. Distribusi Penduduk Terkonfirmasi Positif COVID-19 dan Meninggal Menurut Jenis Kelamin di Indonesia dan DKI Jakarta, 2 Maret - 28 Mei 2020

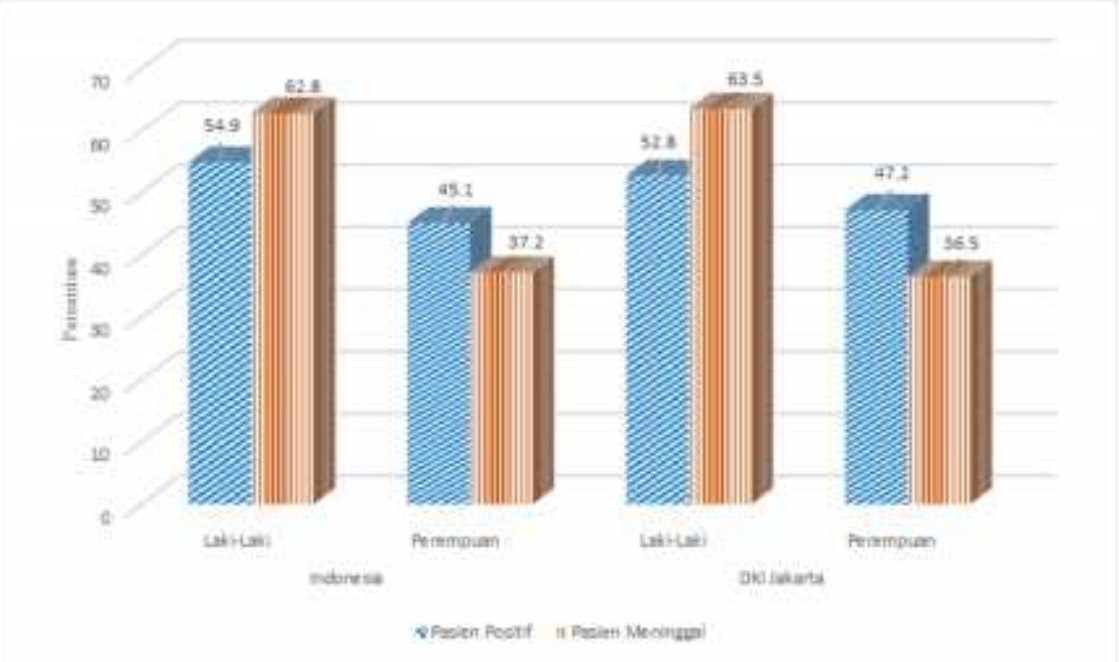

Sumber: Gugus Tugas Percepatan Penanganan COVID-19 Indonesia, 29 Mei 2020

Dominasi penduduk laki-laki yang positif COVID-19 dan meninggal di tingkat nasional juga terjadi di DKI Jakarta. Dari Gambar 3 diketahui bahwa laki-laki yang positif virus korona di Jakarta persentasenya lebih rendah dari diIndonesia. Seperti di Indonesia, kematian laki-laki sangat tinggi, hampir dua pertiga total penduduk yang meninggal di Jakarta. 
Jurnal Kependudukan Indonesia | Edisi Khusus Demografi dan COVID-19, Juli 2020 | 93-100

Gambaran di Indonesia dan DKI Jakarta mengindikasikan penduduk laki-laki jauh lebih rentan terhadap COVID-19 daripada perempuan. Kondisi ini menurut beberapa pakar kesehatan terkait dengan faktor biologis dan gaya hidup. Secara biologis tingkat imunitas laki-laki lebih rendah daripada perempuan, karena itu perempuan relatif lebih kuat bertahan dari virus korona. Sedangkan gaya hidup berhubungan dengan kebiasaan laki-laki yang lebih sering merokok, sehingga penyakit saluran pernafasan laki-laki kondisinya sering lebih buruk daripada perempuan. (Alon dkk., 2020; Lawton, 2020; Mahase, 2020; Promislow \& Phil, 2020; Wenham dkk., 2020). Selain itu, laki-laki lebih terekspose COVID-19, mereka cenderung lebih banyak berada di luar rumah, baik untuk bekerja maupun keperluan lainnya.

COVID-19 juga menyerang semua kelompok umur penduduk, mulai dari bayi-balita sampai dengan lanjut usia (lansia) dengan persentase yang bervariasi menurut kelompok umur (Gambar 3). Penduduk yang terkonfirmasi positif virus korona di Indonesia mengelompok pada tiga kelompok umur, yaitu: 18-30 tahun, 31-45 tahun dan 46-59 tahun dengan persentase tertinggi pada umur 31-45 tahun. Kondisi ini mengindikasikan bahwa penduduk terdeteksi COVID19 terkonsentrasi pada kelompok umur produktif. Mereka lebih terpapar COVID-19 karena banyak berada di luar rumah untuk bekerja. Sebaliknya, penduduk terdeteksi positif paling sedikit terdapat pada kelompok umur 0-5 tahun (bayi dan balita), namun secara kuantitas jumlahnya masih cukup besar, mencapai 564.374 orang pada 28 Mei 2020 (Gugus Tugas Percepatan Penanganan COVID-19 Indonesia, 29 Mei 2020).

Grafik pada Gambar 4 juga menginformasikan penduduk positif COVID-19 yang paling banyak meninggal di Indonesia berada pada kelompok umur 60 tahun ke atas dan umur 46-59 tahun. Kematian penduduk berumur 60 tahun ke atas proporsinya tinggi, mendekati separoh, dari total kelompok umur ini. Sebaliknya, kematian bayi, anak-anak dan remaja (kelompok umur 0-17 tahun) paling rendah $(<1$ persen).

Gambar 4. Distribusi Penduduk Terkonfirmasi Positif COVID-19 dan Meninggal Menurut Kelompok Umur di Indonesia dan DKI Jakarta, 2 Maret - 28 Mei 2020

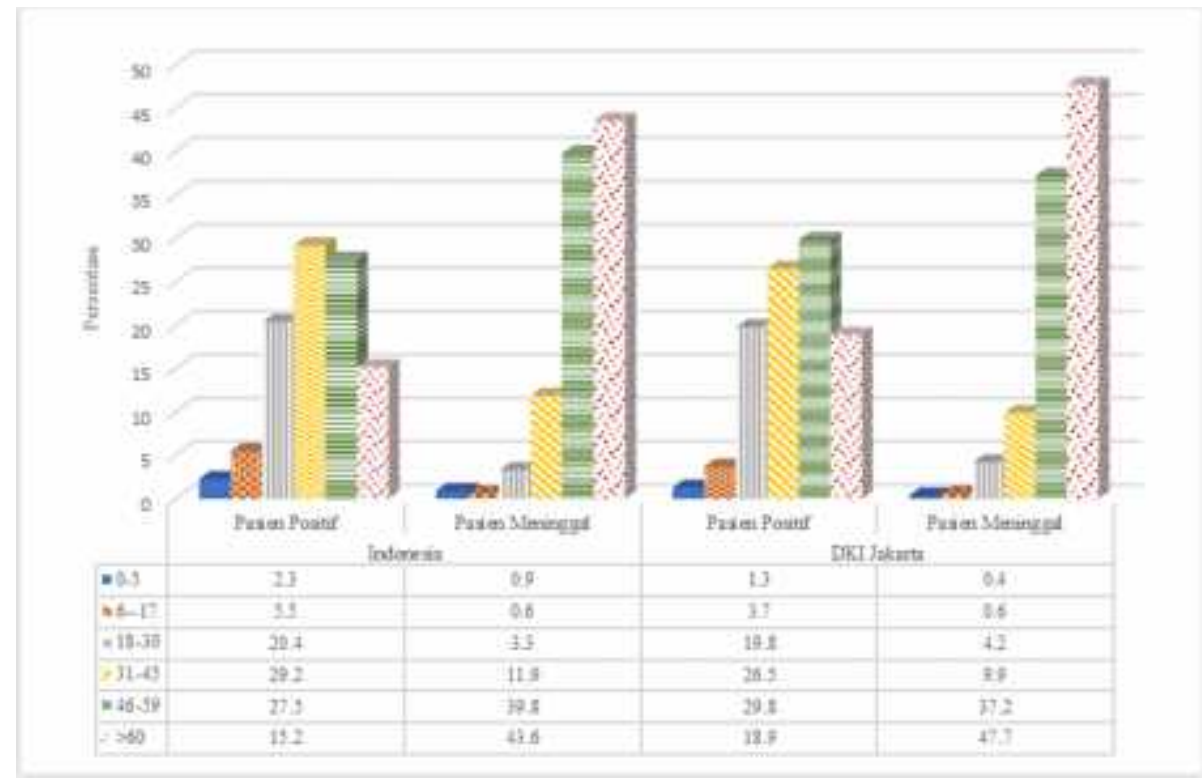

Sumber: Gugus Tugas Percepatan Penanganan COVID-19 Indonesia, 29 Mei 2020

Distribusi penduduk positif COVID-19 dan yang meninggal menurut kelompok umur di tingkat nasional sedikit berbeda dengan di DKI Jakarta. Di Jakarta konsentrasi penduduk yang positif virus korona bergeser ke kelompok umur 46-59 tahun. Sedangkan penduduk positif yang meninggal kondisinya serupa dengan tingkat nasional, mengelompok pada umur 60 tahun ke atas dan 46-59 tahun. 
Kematian penduduk, terutama lansia, erat kaitannya dengan gejala dan penyakit penyerta yang mereka alami (Michelen dkk., 2020; Promislow \& Phil, 2020; Shahid dkk., 2020; WHO, 2020b; Liu dkk., 2020). Data situs resmi pemerintah menginformasikan gejala penyakit utama dari penduduk positif COVID-19 yang meninggal adalah batuk dan riwayat demam dengan persentase di Indonesia sedikit lebih rendah dari di Jakarta. Gejala penyakit tertinggi ke tiga adalah sesak nafas diikuti oleh sakit tenggorokan dan demam. Gejala penyakit lain (seperti: mual, sakit perut, keram otot, dan menggigil) persentasenya lebih rendah dan bervariasi menurut jenis penyakit dengan perbedaan persentase yang tidak signifikan antara jenis penyakit dan lokasi, Indonesia dan DKI Jakarta. (Gambar 2).

Gambar 5. Distribusi Gejala Penyakit Penduduk Positif COVID-19 yang Meninggal di Indonesia dan

DKI Jakarta, 17 Mei 2020 (Persentase)

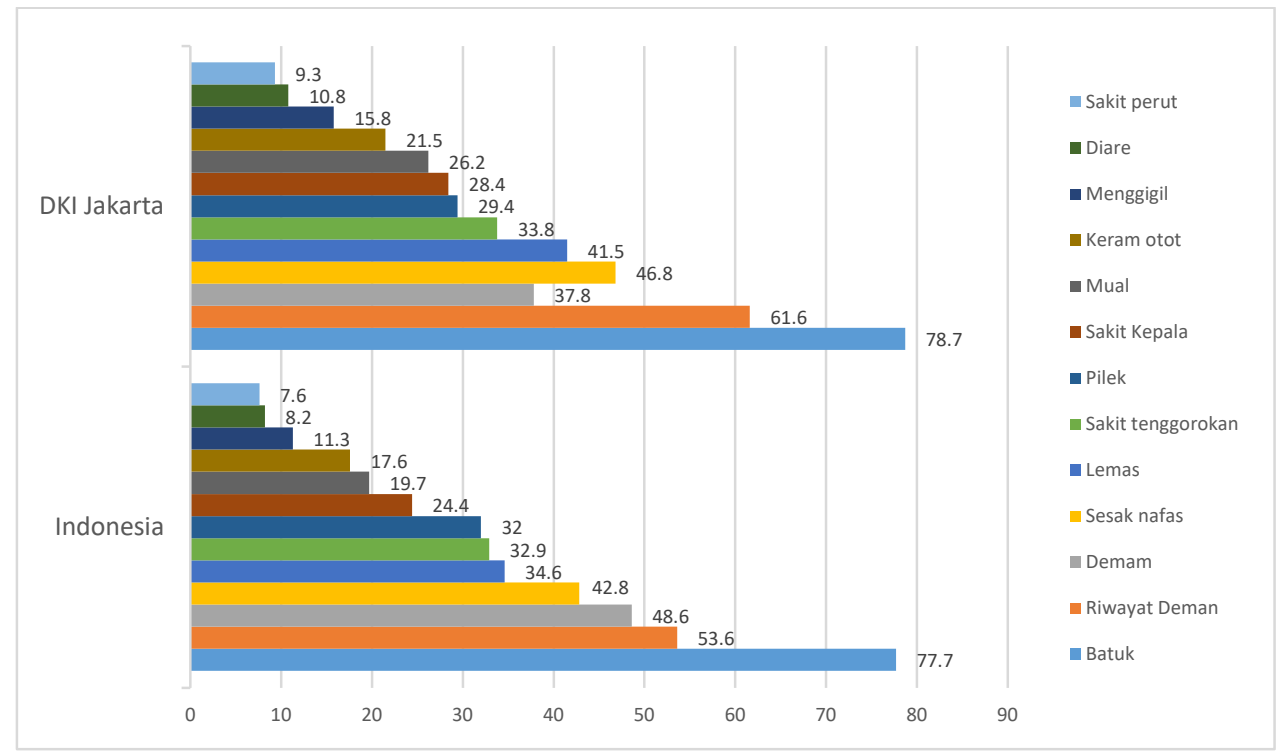

Sumber: Gugus Tugas Percepatan Penanganan COVID-19 Indonesia, 17 Mei 2020

\section{KESIMPULAN}

Paper ini mengungkapkan bahwa penduduk laki-laki dan penduduk berumur di atas 46 tahun, terutama 60 tahun ke atas, rentan terhadap COVID-19 di Indonesia dan DKI Jakarta. Penduduk laki-laki yang terkonfirmasi positif virus korona lebih banyak dari penduduk perempuan dan angka kematiannya jauh lebih tinggi (persentasenya berbeda signifikan) jika dibandingkan dengan kematian perempuan. Namun demikian penduduk perempuan masih harus tetap waspada, karena kemungkinan terinfeksi COVID-19 masih tinggi mengingat perbedaan persentase dengan penduduk
Kebanyakan penduduk yang meninggal juga memiliki penyakit lain (penyakit penyerta) sebelum mereka positif COVID-19. Data situs resmi pemerintah mencatat penyakit penyerta utama dari penduduk positif COVID-19 yang meninggal di Indonesia adalah hipertensi, diabetes militus, jantung dan paru obstruktif kronis. Persentase tertinggi adalah hipertensi mencapai lebih dari separoh penduduk positif virus korona. Sedangkan tiga penyakit penyerta lain persentasenya jauh lebih rendah dari hipertensi. Penyakit penyerta lainnya, seperti penyakit kanker, gangguan nafas lain, ginjal, hati dan asma, persentasenya relatif kecil, kurang dari 10 persen. Pola penyakit penyerta di tingkat nasional ini serupa dengan di DKI Jakarta. (Gambar 5) 
kesiapsiagaan dan mitigasi sangat krusial dan mendesak untuk memutus penyebaran virus korona yang tren pertambahannya masih terus meningkat di Indonesia.

Protokol kesehatan harus dilaksanakan dengan tetap memakai masker, sering mencuci tangan dengan sabun dan air mengalir, menjaga jarak, mengurangi kerumunan warga, dan menjaga pola hidup sehat. Kegiatan sosialisasinya perlu terus digaungkan di ruang publik mengingat sebagian masyarakat tidak disiplin, terutama setelah beredarnya informasi rencana

\section{DAFTAR PUSTAKA}

Alon, T., Doepke, M., Rumsey, J.O., \& Tertilt, M. (2020). The Impact of COVID-19 on Gender Equality. NBER Working Paper 26947. https://doi.org/10.3386/w26947

Centre for Strategic and International Studies [CSIS]. (2020). South East Asia COVID-19 Tracker. https://www.csis.org/programs/southeast-asiaprogram/southeast-asia-covid-19-tracker-0.

Djalante, R., Lassa, J., Setiamarga, D., Sudjatma, A., Indrawan, M., Haryanto, B., Mahfud, C., Sinapoy, M.S., Djalante, S., Rafliana, I. Gunawan, L.A., Surtiarti, G.A.K., \& Warsilah, H. (2020). Review and analysis of current responses to COVID-19 in Indonesia: Period of January to March 2020. ScienceDirect. Progress in Disaster Science, 6, 1-9.

https://doi.org/10.1016/j.pdisas.2020.100091.

Gugus Tugas Percepatan Penanganan COVID-19 Indonesia. (2020). Data COVID-19. https://domainkami.net/index.php/excel/main\#.

Gugus Tugas Percepatan Penanganan COVID-19 DKI Jakarta. (2020).

https://domainkami.net/index.php/excel/main\#.

Lawton, G. (2020, April 16). Why are men more likely to get worse symptoms and die from covid-19?

NewScientist.

https://www.newscientist.com/article/2240898why-are-men-more-likely-to-get-worsesymptoms-and-die-from-covid19/\#ixzz6MBDhOfxp.

Liu, K., Chen, Y., Lin, R., \& Han, K. (2020). Clinical features of COVID-19 in elderly patients: a comparison with young and middle-aged pelonggaran PSBB. Namun sebagian penduduk, terutama di permukiman kumuh, padat dan miskin, sulit menjalankan physical dan social distancing karena kondisi lingkungan dan sosial-ekonomi yang kurang kondusif. Pemerintah dan stakeholders harus menjamin ketersediaan akses mereka terhadap air bersih dan sumber air serta ruang terbuka dan bangunan/ruangan yang diperlukan untuk tempat isolasi/karantina mandiri, terutama bagi penduduk yang telah masuk dalam kategori ODP dan PDP.

patients. J Infect.80 (6), E14-E18

https://doi.org/10.1016/j.jinf.2020.03.005.

Mahase, M. (2020). Covid-19: death rate is $0.66 \%$ and increases with age, study estimates.

$B M J$. https://doi.org/10.1136/bmj.m1327.

Michelen, M., Jones, N., \& Stavropoulou, C. (2020, April 01). In Patients of COVID-19, what are the symptoms and clinical features of mild and moderate cases?. The Centre for Evidence-

Based Medicine. https://www.cebm.net/covid19/ in-patients-of-covid-19-what-are-thesymptoms-and-clinical-features-of-mild-andmoderate-case/.

Promislow, D.E.L.,\& Phil, D (2020). A geroscience perspective on COVID-19 mortality. The journals of gerontology. Series A, Biological sciences and medical sciences, glaa094. Advance online publication. https://doi.org/10.1093/gerona/glaa094

Shahid, Z., Kalayananitra, R., McClafferty, B., Kepko, D., Ramgobin, D., Patel, R., Anggarwal, S., Vunnam, R., Sahu, N., Bhatt, D., Jones, K., Pharm, D., Golamari, R., \& Jain, R. (2020). COVID-19 and older adults: what we know. Journal of the American Geriatrics Society, 68(5), 926-929. https://doi.org/10.1111/jgs.16472.

Wahyuni, N.C. (2020, April 27). Indonesia currently has highest covid-19 mortality rate in Asia. JakartaGlobe. https://jakartaglobe.id/news/indonesia-currentlyhas-highest-covid19-mortality-rate-in-asia.

Wenham, C; Smith, C., \& Morgan, R. (2020). COVID-19: the gendered impacts of the outbreak. The Lancet, 395 (10227), 846-848. https://doi.org/10.1016/S0140-6736(20)305262. 
World Health Organization [WHO] (2020a). International guidelines for certification and classification (Coding) of Covid-19 as cause of death.

https://www.who.int/classifications/icd/Guidelin es_Cause_of_Death_COVID-19.pdf?ua=1.

. (2020b). Updates on novel corona virus (COVID-19).

https://www.who.int/maldives/news/detail/3101-2020-updates-on-novel-corona-virus-

\section{(COVID-}

19)\#: :text=The $\% 20$ virus $\% 20$ can $\% 20$ cause $\% 20$ a, and $\% 20$ deaths $\% 20$ can $\% 20$ occur.

Wong JEL., Leo YS., \& Tan C.C. (2020, Februari 20). COVID-19 in Singapore - current experience: critical global issues that require attention and action.

JAMA 
Jurnal Kependudukan Indonesia | Edisi Khusus Demografi dan COVID-19, Juli 2020 | 93-100 